ISSN 2411-4758 (Print) 2518-1602 (Online)

Native word in ethnocultural dimension, Drohobych, Posvit, 2021, pp. 22-32.

DOI: https://doi.org/10.24919/2411-4758.2021.213090

УДК 81’286(477.85/.87):821.161.2

\title{
ГУЦУЛЬСЬКА МОВНА КАРТИНА СВІТУ КРІЗЬ ПРИЗМУ УКРАЇНСЬКОЇ ХУДОЖНЬОЇ МОВИ
}

\section{Василь ІРЕЩУК,}

доктор філологічних наук, професор, завідувач кафедри украӥнської мови Прикарпатського національного університету імені Василя Стефаника (Івано-Франківськ, Україна) vasyl.greshchиk@рпи.еdи.иа ORCID: https://orcid.org/0000-0002-7011-3911

Researcher ID: N-6078-2018 http://www.researcherid.com/rid/N-6078-2018

\section{Валентина ІРЕЩУК,}

кандидат філологічних наук, доиент кафедри української мови Прикарпатського національного університету імені Василя Стефаника (Івано-Франківськ, Украӥна) valentyna.greshchuk@рпи.еdи.иа ORCID: https://orcid.org/0000-0001-5702-6824

Researcher ID: AAE-8090-2019 http://www.researcherid.com/rid/AAE$\underline{8090-2019}$

Статтю подано до редколегї/The article is submitted to the editorial board:30.09.2020.

Статтю опубліковано/The article is published: 22.02.2021.

У статті проаналізовано словник «Гуиульська діалектна лексика та фраземіка в украӥнській художній мові» як джерело моделювання гуцульської мовної картини світу в українській художній літературі. Основні положення статті грунтуються на тому, щзо засадничими компонентами мовної картини світу с слова як номінативні одиниці. У кожній національній мові означування (найменування) елементів концептуальної картини світу здійснюється передовсім за допомогою номінативних одиниць. Крім поняття загальнонаціональної мовної картини світу, існують регіональні мовні картини світу, лінгвальним підгрунтям яких є місцеві діалекти. Специфіка регіонально-мовної картини світу визначається діалектними мовними формами, оскільки вони називають реалї позамовної дійсності, для яких не знадобилось найменувань у загальноначіональній мові поза діалектним ареалом. Каркас гуцульської мовної картини світу в ї̈ художній версії становлять ключові діалектизми в межах окремих тематичних пластів лексики, лекси- 
кографічно опраџьованих у згадуваному словнику. Лексичні елементи мовної картини світу в українській художній мові охоплюють найрізноманітніші сфери буття й життєдіяльності гуиулів: побут, виробничу сферу, матеріальну й духовну, культуру, вірування, демонологію, природу тощо. У словнику опрацьовано й стійкі словосполучення - фраземи, паремії, прокляття тощо, які суттево доповнюють $і$ збагачують художню версію гуцульської мовної картини світу. Словник в цілому подає обширну інформацію в семантичних характеристиках діалектних номінативних одиниць та в контексті їх використання у літературних текстах і в образно-стилістичних ремаркуваннях, яка дає змогу змоделювати гуиульську мовну картину світу крізь призму української художньої мови.

Ключові слова: мовна картина світу; лексичний діалектизм; словник «Гуиульська діалектна лексика та фраземіка в украӥнській художній мові»; регіонально-мовна картина світу; номінативна одиниця, фразема, паремія.

\section{HUTSUL LANGUAGE PICTURE OF THE WORLD THROUGH THE PRISM OF UKRAINIAN ART LANGUAGE}

\section{Vasyl GRESHCHUK,}

Doctor of Philological Sciences, Professor, Head of the Chair of Ukrainian Language, Vasyl Stefanyk Precarpathian National University (IvanoFrankivsk,Ukraine)vasyl.greshchuk@pnu.edu.ua

\section{Valentyna GRESHCHUK,}

Candidate of Philological Sciences, Associate Professor oh the Chair of Ukrainian Language, Vasyl Stefanyk Precarpathian National University (Ivano-Frankivsk,Ukraine)valentyna.greshchuk@pnu.edu.ua

The article analyzes the dictionary «Hutsul dialect vocabulary and phrasemics in the Ukrainian literary language» as a source of modeling the Hutsul linguistic picture of the world in Ukrainian fiction. The main provisions of the article are based on the fact that the basic components of the linguistic picture of the world are words as nominative units. In each national language, the designation (name) of the elements of the conceptual picture of the world is carried out primarily with the help of nominative units. In addition to the concept of a national linguistic picture of the world, there are regional linguistic pictures of the world, the linguistic basis of which are local dialects. The specificity of the regional-linguistic picture of the world is determined by dialectal language forms, as they name the realities of extralinguistic reality, for which no names were needed in the national language outside the dialectal area. The framework of the Hutsul linguistic picture of the world in its artistic version consists of key dialectisms within certain thematic layers of vocabulary, lexicographically elaborated in the mentioned dictionary. Lexical elements of the linguistic picture of the world in the Ukrainian artistic language cover the most various spheres of life 
and activity of Hutsuls: life, production sphere, material and spiritual, culture, beliefs, demonology, nature, etc. The dictionary also deals with stable phrases - phrasemics, paremias, curses, etc., which significantly complement and enrich the artistic version of the Hutsul language picture of the world. The dictionary as a whole provides extensive information in the semantic characteristics of dialectal nominative units and in the context of their use in literary texts and in figurative and stylistic remarks, which allows to model the Hutsul linguistic picture of the world through the prism of Ukrainian artistic language.

Keywords: linguistic picture of the world; lexical dialectism; dictionary «Hutsul dialect vocabulary and phrasemics in the Ukrainian artistic language»; regional-linguistic picture of the world; nominative unit; phrasema, paremia.

Постановка проблеми. Поняття «мовна картина світу» широко використовується в сучасній лінгвістиці, передовсім тоді, коли йдеться про лінгвалізацію логічної картини світу. Зв'язок логічної і мовної картин світу грунтується на логіко-лінгвальній природі когнітивних процесів. Не випадково автори однієї з перших фундаментальних праць у російському мовознавстві, присвячених аналізу мовної картини світу, в своїй концепції опирались на положення, що «мовна картина світу виконує дві основні функції: 1) означування основних елементів концептуальної картини світу і 2) експлікація засобами мови концептуальної картини світу» (Серебренников, 1988, с. 6). Реалізацію цих функцій здійснюють різнорівневі мовні одиниці та категорії, однак засадничими компонентами мовної картини світу є слова як номінативні одиниці. «Для дискретизації предметних, фактологічних знань й існує в мові універсальний спосіб - найменування предметів і понять про них за допомогою слів» (Серебренников, 1988, с. 111). У кожній національній мові означування (найменування) елементів концептуальної картини світу здійснюється за допомогою таких номінативних одиниць, функціонування яких ареально необмежене, та таких, поширення яких обмежено певною територією ареалу загальнонаціональної мови. Очевидно, що, крім поняття загальнонаціональної мовної картини світу, існують регіональні мовні картини світу, які відображають особливості й специфіку світовідчуття, світобачення етнографічних груп і лінгвальним підгрунтям яких $\epsilon$ місцеві діалекти. «Субстрат регіонально-діалектної картини світу становить говір як мовно-територіальне утворення, що характеризується переважною частиною, спільною з літературним стандартом, та низкою різнорівневих мовних одиниць, властивих тільки цьому говору або йому та іншим, що межують із ним. Однак специфіка регіонально-мовної картини світу визначається діалектними мовними формами, оскільки вони називають реалії позамовної дійсності, для яких не знадобилось найме- 
нувань у загальнонаціональній мові поза діалектним ареалом» (Грещук, 2018, с. 30).

У цій статті ставиться мета висвітлити відображення гуцульської мовної картини світу в мові української художньої літератури. Доброю підмогою дослідження цієї актуальної проблеми стало завершення багатолітньої роботи над створенням інноваційної лексикографічної праці «Гуцульська діалектна лексика та фраземіка в українській художній мові» в двох томах, перший з яких уже опубліковано в 2019 р. (Грещук, 2019), а в цьому році очікується вихід у світ другого тому. Цей словник за теоретико-методологічними засадами відрізняється від традиційних словників гуцульського діалекту (Астаф'єва \& Воронич, 2014; Гуцульські говірки, 1997; Негрич, 2008; Janów, 2001). Він покликаний лексикографічно опрацювати ті гуцульські діалектні слова й стійкі словосполучення, які використані в текстах української художньої літератури. Словникова стаття кожного реєстрового слова, а їх виявилось понад 7,5 тисяч, не враховуючи фонетичних, граматичних й морфологічних варіантів, моделює лексико-семантичну структуру гуцульського діалектизму на основі контекстів його використання в українській белетристиці, демонструє затребуваність художньої мови на ті чи ті лексичні гуцулізми в їх семантичних виявах. Спеціально маркується образне вживання окремих лексико-семантичних варіантів діалектизмів. Гуцульська діалектна лексика, лексикографічно опрацьована в словнику, дає підстави змоделювати гуцульську мовну картину світу крізь призму української художньої мови, яка в якомусь сегменті конгруентна мовній картині світу носіїв гуцульського діалекту, а в якомусь вони не збігаються. Не всі гуцульські діалектні лексичні одиниці чи їх лексико-семантичні варіанти абсорбовані художньою мовою, тому ніяк не відбиті в художній версії гуцульської мовної картини світу. Водночас в українській художній мові засвідчено великий масив діалектних слів, які не потрапили до реєстрів традиційних діалектних словників гуцульського говору, але освоєні мовою української художньої літератури і як такі лексикографічно опрацьовані у згаданому словнику.

Виклад основного матеріалу. Лексичні елементи гуцульської мовної картини світу в українській художній мові охоплюють найрізноманітніші сфери буття й життєдіяльності гуцулів: побут, виробничу діяльність, матеріальну й духовну культуру, вірування, демонологію, природу тощо. Каркас гуцульської мовної картини світу в іiі художній версії становлять ключові діалектизми в межах окремих тематичних пластів лексики. Так, побут горян в ділянці одягу репрезентує низка знакових 
слів-гуцулізмів, які структуровані за різними функційно-семантичними ознаками в дрібніші лексико-семантичні угруповання. Гуцульськими загальними назвами одягу в українській художній мові є лудинє (його фонетичні варіанти лудині, лудиння, лудінє, лудіннє, лудина, лудіння, лудження) уберя (вберя), ноша, фантє). При цьому лудинє означає здебільшого святковий одяг, функційно найближчими до нього є уберя та ноша, а фантє зазвичай стосується будь-якого одягу.

Важливим елементом гуцульської мовної картини у художній версії $\epsilon$ типово гуцульські діалектизми гачі 'верхні чоловічі штани 3 домотканого полотна або сукна' та крашениці (гачі-крашениці), внутрішня форма яких вказує, що штани пофарбовані зазвичай у червоний колір. На позначення чоловічих полотняних штанів, здебільшого спідніх, у гуцульському говорі функціонують ще спільнокореневі номінації nорmки і партєниці.

Предметом лише чоловічого одягу є також черес 'широкий шкіряний пояс з кишеньками і пряжками, переважно оздоблений’ та кресаня (крисаня, крісаня), які освоєні мовою української художньої літератури.

Тільки жіночий гуцульський одяг репрезентують діалектизми тулля 'верхній одяг без рукавів у вигляді накидки з капюшоном, виготовлений з білого домотканого сукна, що використовується переважно як весільний одяг молодої', опинка 'поясний жіночий одяг із одного незшитого полотна'.

Окремі предмети гуцульського одягу, який носять як чоловіки, так і жінки, категоризовано лексичними діалектизмами кептар (кunтар, кunmapb, кіnтар) 'короткий кожушок без рукавів, пошитий із білої овечої шкіри, зрідка з козячої, зазвичай оздоблений орнаментом із кольорових ниток, шкіри, металу', сардак (сердак, сирдак) 'верхній короткий рукавний чоловічий або жіночий одяг із домотканого сукна, оздоблений вовняними нитками'.

Якщо взяти до уваги ще й інші гуцульські назви одягу, лексикографічно опрацьовані в словнику, то разом із уже проаналізованими вони дають доволі повне уявлення про те, як одягались горяни, чим відрізнявся їхній одяг від інших людей. Як і гуцульські назви їжі: натинка 'рідка страва з молодої лободи і кукурудзяних крупів', дзєма 'юшка', сербавка 'рідкий суп, зазвичай без м'яса', кулеша 'густа страва з кукурудзяної муки, варена на воді', бануш (бануж), бануша 'густа страва з кукурудзяної муки, варена на сметані', чир 'рідка страва, переважно з кукурудзяної муки', буджениці (бужениці, буженицуа, бужениця) 'копчене м'ясо, попередньо просолене й приправлене прянощами; шинка', солонина 'сало', студенец 'холодець', джорина 'шкварок', малай (мелай) 'хліб 
3 кукурудзяного борошна', обарінок 'калачик, бублик', жилавничьок 'невеликий хліб із ячмінної муки', барабуляник, бурєшенник (бурєшінник, буришєник, буришіник, буришник, бурішинник, буреник) 'печений картопляний корж', матаржсник 'печений корж з картоплі та інших овочів', мандрусь 'корж поганої якості, спечений із лободи, кропиви, інших рослин', бриндза (бриндзя, бринза, бринзя) 'спеціально приготовлений для зберігання посолений сир', будз (буи) 'овечий сир із свіжого молока у формі кулі, який висушували для приготування бриндзи', гуслєнка (гуслінка, гусльинка, гуслянка) 'спеціально заквашене густе кипячене молоко', розвод 'розведена водою гуслянка', буришка (бурешка, бур'єшка, боришка, баришка, бурка) 'картопля', пироги 'вареники' та ін. формують сегмент гуцульської мовної картини світу в ділянці харчування. Зазначені слова як носії дискретизованих знань про продукти харчування, їх приготування, споживання, об'єктивованих у лексичних значеннях діалектизмів, становлять основу окремого пазла інтерпретації побуту гуцулів.

Аналогічне простежуємо в гуцульських діалектних назвах житла, меблів, господарських предметів, посуду й кухонного начиння, знарядь праці, свійських тварин, обрядів, забав, розваг тощо аж до повного охоплення всієї побутової сфери, як засвідчують матеріали словника ${ }^{1}$. Отже, на діалектизмах, що позначають побутові предмети, артефакти, події, явища, лексикографічно опрацьованих у словнику, грунтується сегмент гуцульської мовної картини в ділянці побуту горян.

Так само в лексичних значення гуцульських діалектних слів всіх інших тематичних сфер об'єктивовано знання, які уможливлюють моделювання світобачення, світосприймання цих сегментів світу, а, зведені в єдину систему, вони творять загальну гуцульську мовну картину світу. Специфіку й неповторність мовного образу світу гуцулів зумовлює саме діалектна лексика, включена в лінгвалізацію дійсності.

Це добре простежується на матеріалі демонологічної лексики, яка увиразнює специфіку, оригінальність і неповторність гуцульського сприймання й світорозуміння дійсності. Словник «Гуцульська діалектна лексика та фраземіка в українській художній мові» засвідчив повноту використання у художніх текстах демонологічної лексики і їі роль у художній інтерпретації вірувань горян, їхньої міфології, їхнього світогляду загалом. Серед цієї лексики виділяються найменування власне міфічних істот та назви людей, наділених надприродною силою, так звані «непрості». Вони репрезентують різні світи, однак П. Ю. Гриценко слушно вважає, що «ці два світи, традиційно оцінювані як опозитивні,

${ }^{1}$ Детальніше див. 1. 
навіть ворожі, не відділенні неперехідною межею. Сднальною ланкою між ними є не лише антропоморфне начало у творенні людською уявою міфічних істот, не лише моделювання цього позалюдського світу за зразком людського, життя людського соціуму, а й структура демонічного простору, у якій виразно окреслюються зони, перехідні до світу людей. Грань між світом людей і світом демонів зневиразнена завдяки існуванню повір'їв (Гриценко, 2002, с. 3-4). Словник лексикографічно інтерпретує назви таких витворених гуцульською, за словами М. Коцюбинського, буйною фантазією персонажів, як арідник 'злий дух, чорт, дідько' і низку синонімічних для них назв - антипко, біда, той, щзезби, щеезник, осинавець, пекун, помічник, юда, хованець, окаменюшник, дзябол (дьябол), інклюз (инклюз, никлюз), інклюзник, юрчик, гонихмарник, шатан, невмиваний та ін.

Мова української художньої літератури засвідчила низку гуцульських найменувань інших міфічних істот, опрацьованих у словнику, зокрема чугайстер (чугайстир) 'добрий і веселий лісовий дух який оберігає людей від лісових мавок’ та синонімічні номінації лісун, дикун; лісна 'лісова дівчина, яка являючись чоловікові, може змінювати зовнішність на подобу ііі коханої і причаровує його', а також синонімічні назви нявка, лісовиия, лісова дівка; нічниця 'міфічна істота в образі дівчини, яка забирає сон і викликає безсоння, завдає шкоди людині'; нетленник 'чоловік, який живе у лісі і знає долю новонароджених' та ін.

«Непрості» чи «земні боги» у словнику репрезентовано діалектизмами баӥльник 'знахар; чоловік, який лікує замовляннями', віжлун (відун) 'людина, яка вгадує, передбачає, пророкує майбутнє; віщун', вовкун 'людина, що обертається у вовка; вовкулак', гадєр (гадяр) 'чоловік, який замовляє від укусу гадюк, або має владу над ними', градівник 'людина, яка володіє даром відвертати грозові хмари', мольфар (мольфарь, мальфар) 'чоловік, який володіючи особливими знаннями про довколишній світ, може завдавати шкоди чи приносити користь людям; чаклун, ворожбити, знахар', чередінник 'чоловік, який може завдавати шкоди людині чи тварині, переважно відбираючи молоко в корів', чінатарь 'чоловік, який чарами може завдавати шкоди людині чи тварині; чаклун' та ін.

Словник «Гуцульська діалектна лексика та фраземіка в українській художній мові» «засвідчує, що для мовної картини світу гуцулів демонологічна лексика актуальна, значуща, семантико-символічно наснажена. Без цієї лексики гуцульська вербальна модель світу буде неповною і збідненою й неадекватно відображатиме світогляд, культуру гуцулів» (Грещук, 2019, с. 303). 
У словнику «Гуцульська діалектна лексика та фраземіка в українській художній мові» опрацьовано й стійкі словосполучення - фраземи, паремії, прокляття тощо, які суттєво доповнюють і збагачують художню версію гуцульської мовної картини світу. Так, до уже згадуваного гуцульського діалектного слова гачі словникова стаття подає низку фразем із ним, зокрема в гачі вбрати 'перехитрити', багач без гач ірон. 'щедрий', мудрий, як Гершкові гачі ірон. 'надзвичайно мудрий', накласти повні гачі зневажл. 'дуже злякатися', наробити в гачі зневажл. 'перелякатися', трясти гачами зневажл. 'лякатися, боятися, трястися'.

У мовній картині світу фраземи виконують специфічні функції. М. Демський зазначив: «Фраземи, принаймі наявні в слов'янських мовах, мають одну дуже цікаву властивість: вони позначають далеко не все пізнане людиною, а лише ті моменти, які з точки зору мовного колективу необхідно представити образно, емоціонально, експресивно» (Демський, 1997, с. 8). Стійкі словосполучення розбудовують, збагачують і доповнюють образну емоційно-експресивну компоненту гуцульської художньо-мовної картини світу, відбиваючи в тому числі психологію, психотип, характер, вдачу гуцула.

Кожна фразема за своїми структурно-семантичними особливостями тісно пов'язана з гуцульським світом. Передовсім це лексичний діалектизм як компонент стійкого словосполучення: нагнати (кому-небудь) кози на бер 'погрожувати комусь чимось лихим', зиграти на бербенииу (про ногу) 'дуже розпухнути', три міхи і двоє бесаг 'дуже багато', дурна бола 'епілепсія', дати понюхати бартку 'побити когось', боридка зливкала 'хтось налякався', бути в спитку з позаторішньою бринзею ‘бути дуже голодним', без брича бритися мож 'про гостру на язик, дошкульну людину', котюжий перелаз 'ласий до жінок чоловік, жіночий звабник, спокусник’ та ін. Деякі фраземи містять гуцульській онім, який маркує гуцульськість фраземи, пор.: піти як та крига весною на Черемоші 'померти', на Гуиульщині когут на три держави піє 'один народ під владою трьох держав' та ін.

Прислів'я та приказки теж в образній формі фіксують особливості світосприймання гуцулів і $є$ важливими елементами гуцульської мовної картини світу, пор.: кайси не кайси, а єк си стало, то заткайси 'якщо вже щось трапилось, то пізно каятися', отаке із корови кєгло як із баб восько 'з жінок погані, ніякі воїни, як із корови тяглова сила', так си бою, як кіт лою 'зовсім не боюся', ліпшя из своєї печі росівниця, єк з чужеї печі книші 'краще своє, хоч і погане, ніж навіть дуже добре чуже, там зле ся діє, де не когут, а курка піє 'там немає добра, де жінка керує, а не чоловік', щзо кому смакує, най здоров пакує 'про безволь- 
ну, безхарактерну людину', не боїться коза вовка, доки не вздрит, а єк уздрит, то ни своїми голосами верешіт - ни-и-и ме-е-ене-е-е "про хвальковитих, але боязливих людей', хто потопаєт, mom си за брич xanaєm 'хтось намагається використати будь-яку, навіть і безнадійну, можливість вийти із скрутного становища, врятувати себе', віддай бук, най тебе пси рвуть 'нашкодити самому собі зробити собі гірше', валенцатиси по селу добувати киселю зневажл. 'вештатися', голод калюxи nорет 'про стан, коли немає що їсти, хто-небудь голодує', як $є$ хліб $i$ вода, то нема голода 'про мінімум засобів, необхідних для прожитку, існування без голоду', твій рик криз гудзииу проник згруб. 'ніщо не діє, не впливає; марні старання'.

Важливим компонентом гуцульської мовної картини світу є стійкі словосполучення, які фіксують прокляття і виражають побажання смерті: розсівбисси на маки макенні, най тебе нагла кров заллє, кров пив би собі із-за нігтів, аби громи (кого-небудь) убили (спалили), най го шляк трафит, бодай би (когось) викришило до дитини, до пня й до сухого листу, бодай би щзезла та ін. Інші, використовуючись як прокляття, виражають різні нещастя, які можуть випасти на долю людини: аби ти тодi доробився, як вода горі піде, бодай би (комусь) так легко на світі жити, бодай би (когось) кучмарі поганили, а води Божої ни нахлебав бес-си, збавив би Біг комусь долю, упала би на тє біда, єк нічь на хати, робила би (кому-небудь) біда ребра на спаню, хоробочка би утєла (когось), а недочеканє твоє, най й'му горло у черево затєгне, най грими, куда си направив та ін.

Всі прокляття глибоко занурені в гуцульський світ, їх поява зумовлена гнівом, обуренням, роздратуванням, сплавом емоцій гуцула в складних життєвих ситуаціях. Деякі з них поза Гуцульщиною, ії історією, матеріальною та духовною культурою важко збагнути, наприклад, побила би тє Гердліччіна ниволя тай Юріштанова рука, аби (когось) смерека втела та ін.

Висновки та перспективи подальшого дослідження. Отже, словник «Гуцульська діалектна лексика та фраземіка в українській художній мові» подає обширну інформацію в семантичних характеристиках діалектних номінативних одиниць та в контексті їх використання у літературних текстах і в образно-стилістичних ремаркуваннях, яка дає змогу змоделювати гуцульську мовну картину світу крізь призму української художньої мови. Перспективи подальшого дослідження зазначеної проблеми полягають у порівняльному вивченні художньої мовної картини гуцулів та гуцульської діалектної мовної картини. 


\section{СПИСОК ЛІТЕРАТУРИ}

Астаф'єва, М. М. \& Воронич, Г. В. (2014). Словник гуцульських говірок Річки mа Яворова: У 4-х книгах. Івано-Франківськ: Місто НВ. Кн. 1. А - Ж.

Гриценко, П. (2002). До проблеми лінгвістичного опису українського демонімікону. Наталя Хобзей. Гуиульська міфологія: етнолінгвістичний словник. Інститут українознавства ім. І. Крип'якевича НАН України, 3 - 18.

Грещук В. (Відп. ред.). (2019). Гуцульська діалектна лексика та фраземіка в украӥнській художній мові. Словник: У 2 т. Івано-Франківськ: Місто НВ. Т. 1.

Гуиульські говірки. Короткий словник. (1997). Львів: Інститут українознавства ім. І. Крип'якевича НАН України.

Грещук, Василь, Грещук, Валентина. (2015). Діалектне слово в тексті та словнику. Івано-Франківськ: Місто НВ.

Грещук, Василь, Грещук, Валентина. (2018). Мовна картина світу крізь призму художньої мови. Полонина. Рідне слово в етнокультурному вимірі: зб. наук. праць. Дрогобич: Посвіт, $28-38$.

Демський, Мар'ян. (1994). Українські фраземи й особливості їх творення. Львів: Просвіта.

Негрич, М. (2008). Скарби гуцульського говору: Березови. Львів: Інститут українознавства ім. І. Крип'якевича НАН України.

Серебренников, Б. А. (Відп. ред.). (1988). Роль человеческого фактора в языке: Язык и картина мира. Москва: Наука.

Хобзей, Н., Сімович, О., Ястремська, Т. \& Дидик-Меуш, Г. (2013). Гуиульські світи: Лексикон. Львів: Інститут українознавства ім. І. Крип’якевича НАН України.

Janów, J. (2001). Słownik huculski. Kraków : Wydawnictwo Naukowe DWN.

\section{REFERENCES}

Astafyeva, M. M \& Voronich, G. V. (2014). Slovnyk hutsul's'kykh hovirok Richky ta Yavorova: U 4-kh knyhakh. [Dictionary of Hutsul dialects of Rivers and Yavorov: In 4 books]. Ivano-Frankivsk: City of NV. Book 1. A - Ж. [in Ukrainian]

Gritsenko, P. (2002). Do problemy linhvistychnoho opysu ukrayins'koho demonimikonu/ [To the problem of linguistic description of the Ukrainian demonimicon]. Natalya Khobzey. Hutsul's'ka mifolohiya: etnolinhvistychnyy slovnyk. Instytut ukrayinoznavstva. [Natalia Hobzey. Hutsul mythology: ethnolinguistic dictionary]. Institute of Ukrainian Studies. I. Krypyakevych of the National Academy of Sciences of Ukraine, 3 - 18. [in Ukrainian]

Greshchuk V. (Ed.). (2019). Hutsul's'ka dialektna leksyka ta frazemika v ukrayins'kiy khudozhniy movi. Slovnyk: U 2 t. [Hutsul dialect vocabulary and phrasemics in the Ukrainian artistic language]. Dictionary: In 2 volumes. Ivano-Frankivsk: City of NV. T. 1. [in Ukrainian]

Hutsulski hovirky. Korotkyy slovnyk. [Hutsul dialects. Short dictionary]. (1997). Lviv: Institute of Ukrainian Studies. I. Krypyakevych of the National Academy of Sciences of Ukraine. [in Ukrainian] 
Greshchuk, Vasil \& Greshchuk, Valentina. (2015). Dialektne slovo v teksti ta slovnyku. [Dialect word in the text and dictionary]. Ivano-Frankivsk: City of NV. [in Ukrainian]

Greshchuk, Vasil \& Greshchuk, Valentina. (2018). Movna kartyna svitu kriz pryzmu khudozhnoyi movy. Polonyna. [Linguistic picture of the world through the prism of artistic language. Polonina]. Ridne slovo $v$ etnokulturnomu vymiri: zb. nauk. prats - Native word in the ethnocultural dimension: Coll. Science. Drohobych: Posvit. 28 - 38. [in Ukrainian]

Demsky, Marian. (1994). Ukrayinski frazemy y osoblyvosti yikh tvorennya. [Ukrainian phrases and features of their creation]. Lviv: Prosvita. [in Ukrainian]

Negrich, M. (2008). Skarby hutsulskoho hovoru: Berezovy. [Treasures of the Hutsul dialect: Birches]. Lviv: Institute of Ukrainian Studies. I. Krypyakevych of the National Academy of Sciences of Ukraine. [in Ukrainian]

Serebrennikov, BA (Resp. Ed.). (1988). Rol chelovecheskoho faktora v yazyke: Yazyk y kartyna myra. [The role of the human factor in language: Language and the picture of the world]. Moscow: Science. [in Russian]

Hobzey, N., Simovich, O., Yastremskaya, T. \& Didyk-Meush, G. (2013). Hutsulski svity: Leksykon [Hutsul worlds: Lexicon]. Lviv: Institute of Ukrainian Studies. I. Krypyakevych of the National Academy of Sciences of Ukraine. [in Ukrainian]

Janów, J. (2001). Słownik huculski. Kraków: DWN Scientific Publishing House. [in Polish] 